\title{
Highlights from the Northwest Territories BioBlitzes
}

To mark Canada's 150th anniversary, BioBlitz Canada 150 , a national partnership of nature organizations, brought together the Canadian public with scientists to explore the richness of Canada's biodiversity and to engage our passion to know, celebrate, and conserve our natural heritage. It became known as "Canada's Nature Selfie". The Canadian Wildlife Federation with BioBlitz Canada and other partners in conservation, carried out a series of public BioBlitzes across the nation (Canadian Wildlife Federation 2017). A BioBlitz is an intense period of biological surveying (usually 24 hours) by scientists, naturalists, volunteers, and keen members of the public, in an attempt to record as many living species as possible from a given area. These day-long BioBlitz events are hugely valuable for public outreach, education, and for collecting biological data, including discovery of species not previously known from an area.

The Government of the Northwest Territories organized BioBlitz events in five communities: Inuvik, Tuktoyaktuk, Norman Wells, Fort Simpson, and Yellowknife. New species records for the region are not the only results. Just as important are examples of new information on environmental changes, sharing local knowledge, and helping children to protect and understand nature.

Tuktoyaktuk (28 July 2017, Government Offices, The Point, $69.4507^{\circ} \mathrm{N}, 133.0370^{\circ} \mathrm{W}$ ). The main BioBlitz event took place on the tip of the peninsula in town, locally called "The Point". This area had hundreds of plants of the spectacular Marsh Felwort (Lomatogonium rotatum (L.) Fries). This bright blue-flowered plant is characteristic of cold seashores. The $5 \mathrm{~cm}$ long benthic marine isopod Saduria entomon (Figure 1) was recorded along the shoreline. Although not the first time it was observed in Tuktoyaktuk —or "Tuk"-(Percy 1983), it may have been the first time this circumarctic creature had been called by its international (scientific) name. Meadow Slug, Deroceras laeve, observed in Tuk and along the shoreline to the west of town is one of the northernmost records in Canada. Among the birds observed in Tuk was the Red-necked Phalarope (Phalaropus lobatus; Figure 2), which has experienced major declines in some migratory staging areas. This phalarope has been recently designated as "Special Concern" (COSEWIC 2014a) by the national committee that assesses species at risk in Canada and recommends species for listing under the federal Species at Risk Act. Our observations of these birds (and those of others) may help to understand the environmental changes that have caused these declines (and that may influence many other species). We wondered whether American Robins (Turdus migratorius) around town may be a new record in Tuk, but in fact these birds were reported over a century ago from groups of trees on the barren lands by Preble (1908).

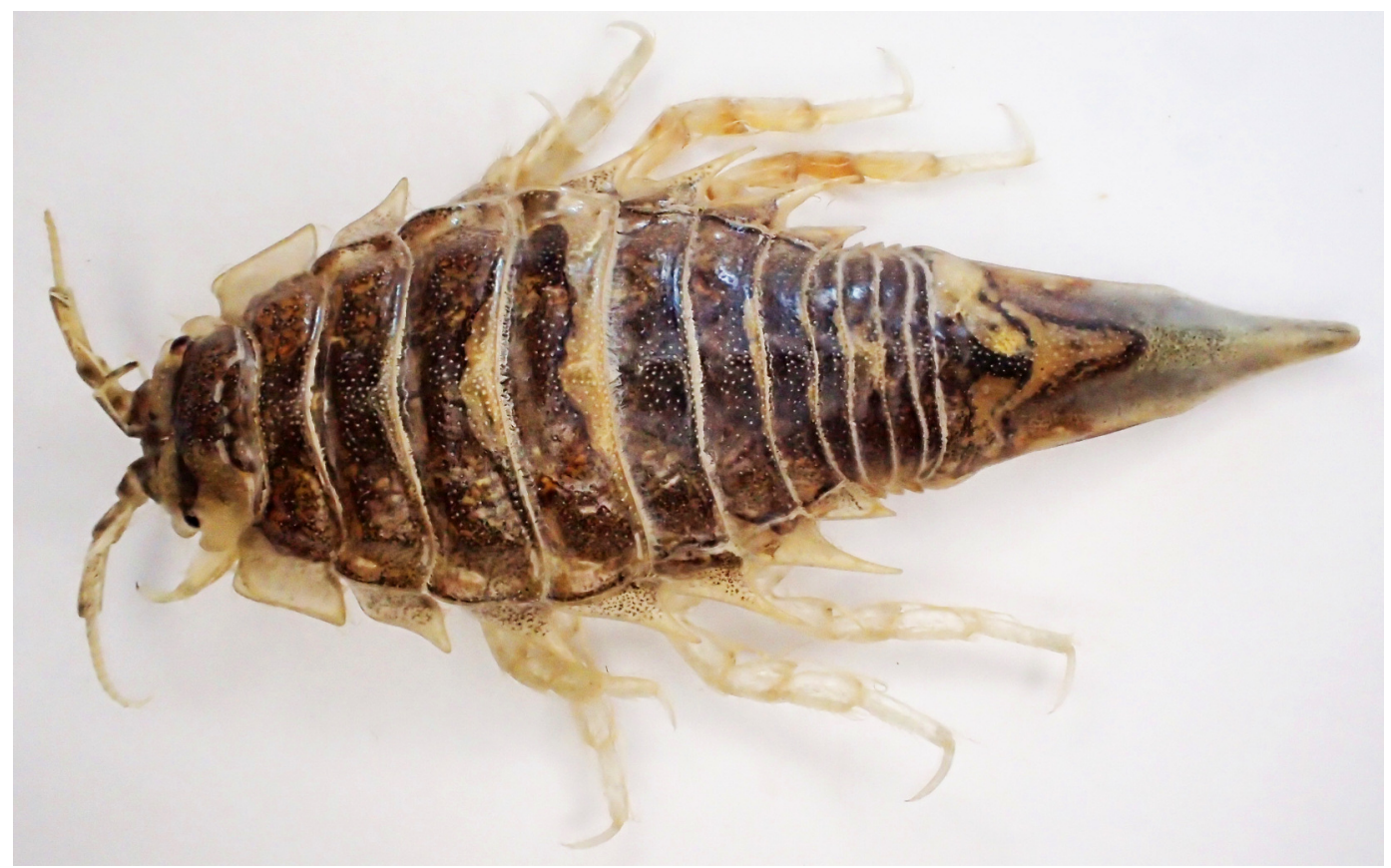

Figure 1. The isopod crustacean, Saduria entomon (Chaetiliidae) from the Beaufort Sea, Tuktoyaktuk. 27 July 2017. Photo: P. M. Catling. 


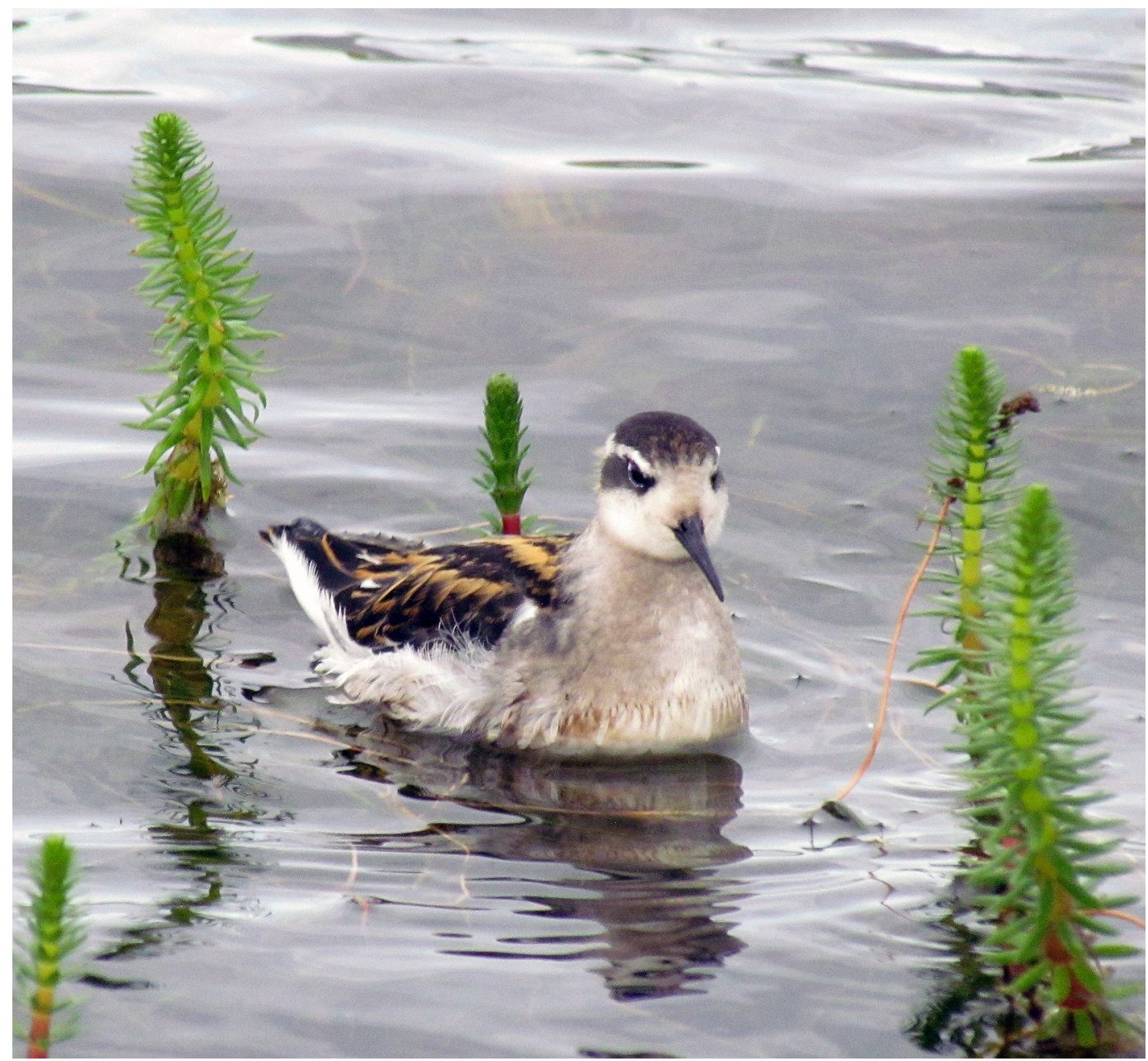

Figure 2. Red-necked Phalarope (Phalaropus lobatus) in a pool on Ocean Drive, Tuktoyaktuk. 26 July 2017. Photo: P. M. Catling.

Local people had the most significant bird observations. We were told that 15 years ago there were very few Bald Eagles (Haliaeetus leucocephalus) around Tuk but they have become more common along the Arctic Coast and at the time of the BioBlitz there were 20 observed during our stay in town. We also learned that more Arctic Char (Salvelinus alpinus) were being caught and the salmon caught recently had not been caught before. Also, there were several observations of Bowhead (Balaena mysticetus) and Beluga (Delphinapterus leucas) whales in August (2016 and 2017).

One of the most fascinating biological areas of town included the south pingo. We completed numerous vegetation transects across the pingo that yielded detailed plant lists which will provide a basis for future monitoring related to climate change. Many of the plants on the pingo have a restricted northwestern Arctic distribution, such as Narrow-leaved Saw-wort (Saussurea angustifolia (L.) de Candolle; Figure 3). A true wild orchid, Early Coralroot (Corallorhiza trifida Châtelain) was also found in this unusual plant assemblage.

Numerous bumble bees were noted in Tuktoyaktuk including Brown-tailed Bumble Bee (Bombus mixtus), Red-tailed Bumble Bee (Bombus sylvicola; Figure 4), Yellow-faced Bumble Bee (Bombus flavifrons), and Orange-rumped Bumble Bee (Bombus melanopygus). These species have been recorded from the Northwest Territories (NWT) before, but noting their abundance in Tuk confirms their distribution in the area and also provides a baseline for future study.

Inuvik (30 July 2017, Aurora Centre to Boot Lake Trail, $\left.68.3558^{\circ} \mathrm{N}, 133.7206^{\circ} \mathrm{W}\right)$. The BioBlitz event in Inuvik attracted over 35 people of all ages and followed the main trail part way around Boot Lake (Figure 5). Three hundred plants of the unusual cone-like parasite (on alder) Ground-Cone (Boschniakia rossica (Chamis- 


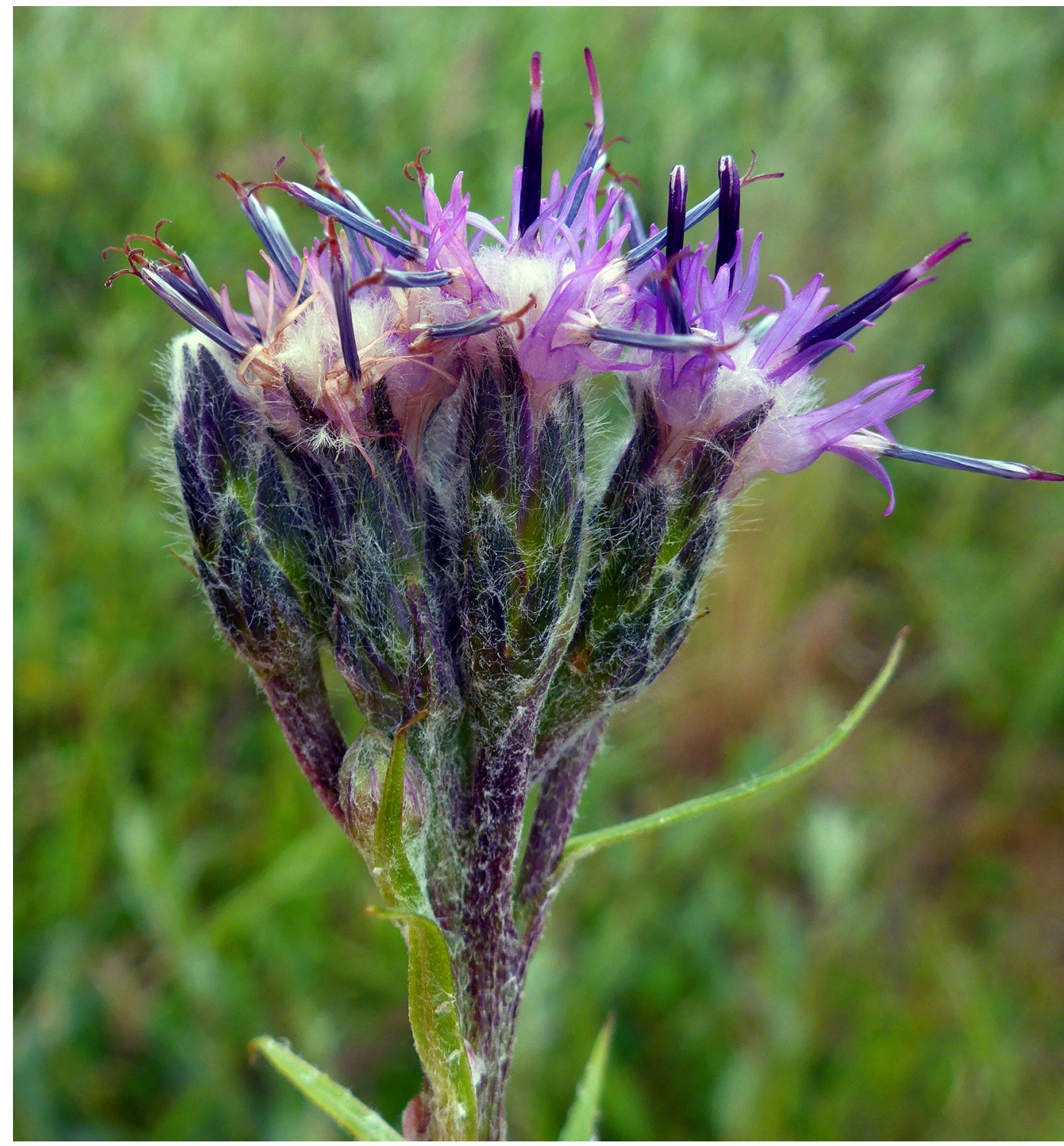

FIgURE 3. Narrow-leaved Saw-wort (Saussurea angustifolia) on Tuktoyaktuk's south pingo. 25 July 2017. Photo: P. M. Catling.

so \& Schlechtendal) B. Fedtschenko) were found, more than had been observed in one small area before. Along the Mackenzie River were occasional Wood Frogs (Lithobates sylvaticus; Figure 6), which are abundant elsewhere in the Mackenzie River delta (for example at Aklavik). The Mackenzie River Delta Wood Frog population is the northernmost population of any frog in Canada.

On the day prior to the Inuvik BioBlitz, both Grizzly Bears (Ursus arctos) and Black Bears (Ursus americanus) were seen on the Boot Lake trail, but to the relief of some attendees our noisy group of 35 people dis- couraged an appearance. Everyone wanted to know about what looked like fluorescent orange spray paint on the wild Prickly Roses (Rosa acicularis Lindley). To many people's surprise, this was not paint but the spectacular powdery rust fungus, Phragmidium (Figure 7). The equally remarkable prickly gall on the rose plants along the trail was caused by a minute chalcidoid gall wasp of the genus Diplolepis (possibly D. bicolor; Figure 8). An interesting observation was that of Bill Halliday, who identified a Northern Red-backed Vole (Myodes rutilus) from bones regurgitated by an owl along the Boot Lake trail. 


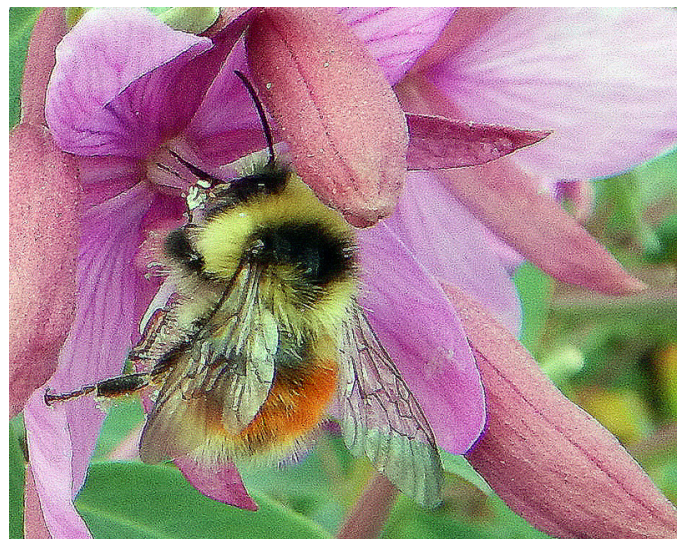

Figure 4. Red-tailed Bumble Bee (Bombus sylvicola) at Tuktoyaktuk. 27 July 2017. Photo: J. Heron.

The gravelly open areas along roadsides, around utilidors (utility pipes), and in yards of Inuvik are rich in native vascular plant species, unlike such habitats further south. These included attractive wildflowers such as Alpine Milk-vetch (Astragalus alpinus L. var.

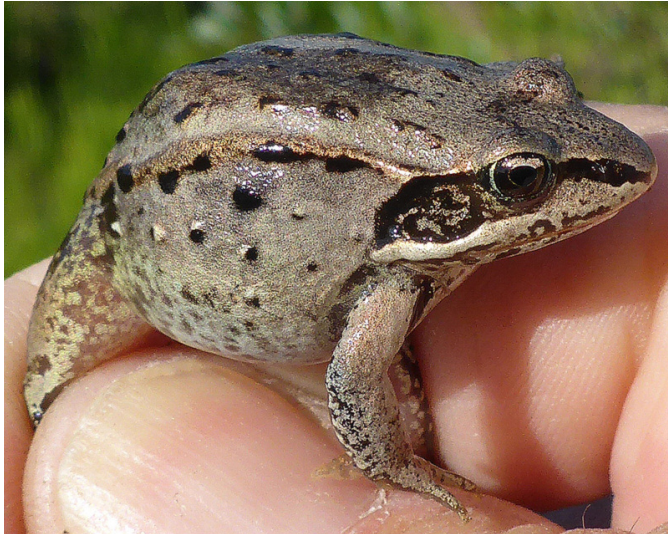

FIGURE 6. Wood Frog (Lithobates sylvaticus) from Twin Lakes, Inuvik. The Mackenzie Delta population are the northernmost frogs in Canada. 30 July 2017. Photo: P. M Catling.

alpinus), Marsh Grass-of-Parnassus (Parnassia palustris L.), Nodding Locoweed (Oxytropis deflexa (Pallas) de Candolle subsp. foliolosa (Hooker) Cody), and Raup's Paintbrush (Castilleja raupii Pennell). Rich native wildflower habitats of this kind are uncommon

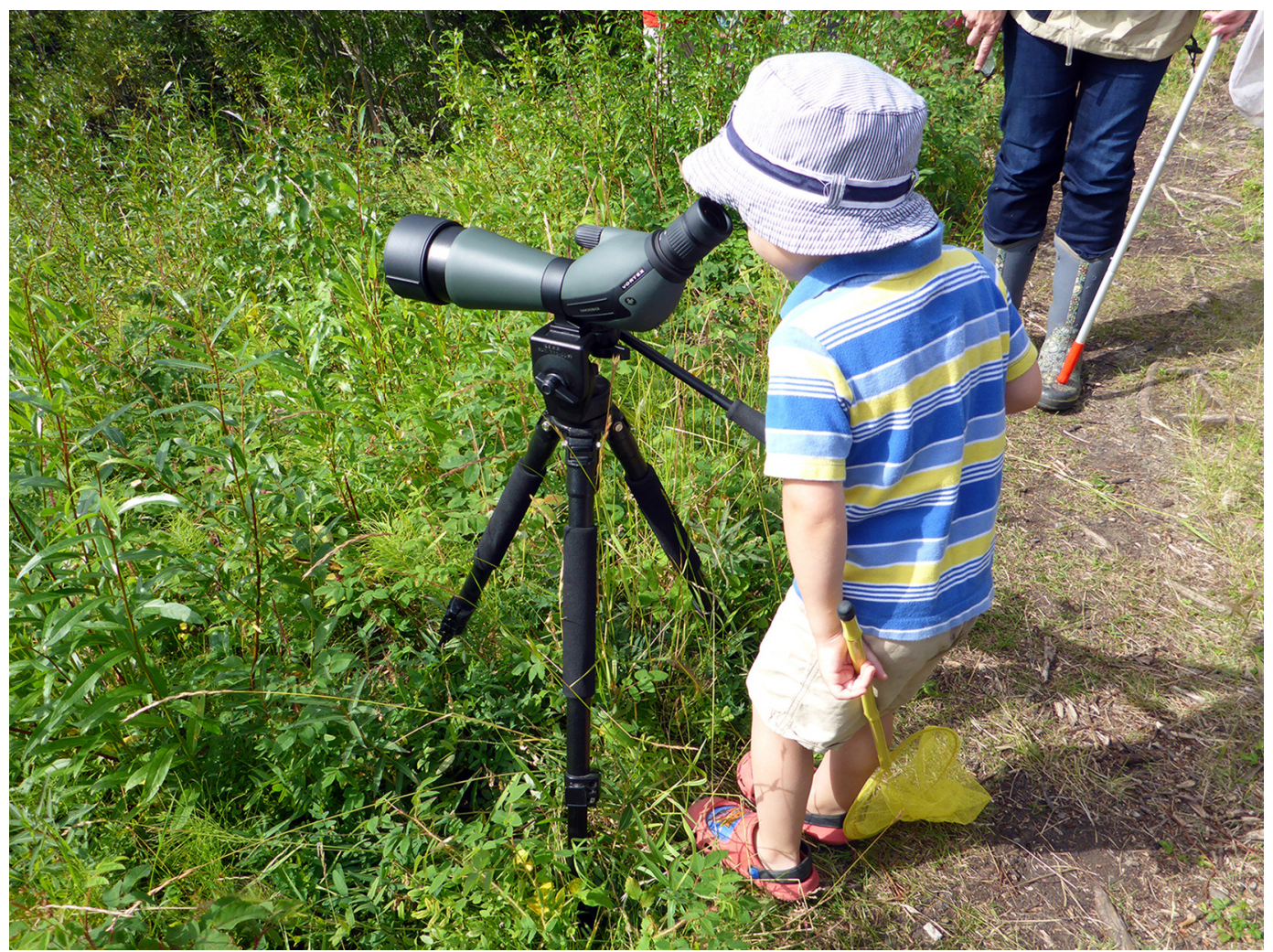

FIGURE 5. Monitoring ducks on Boot Lake during the Inuvik BioBlitz. 30 July 2017. Photo: B. Kostiuk. 


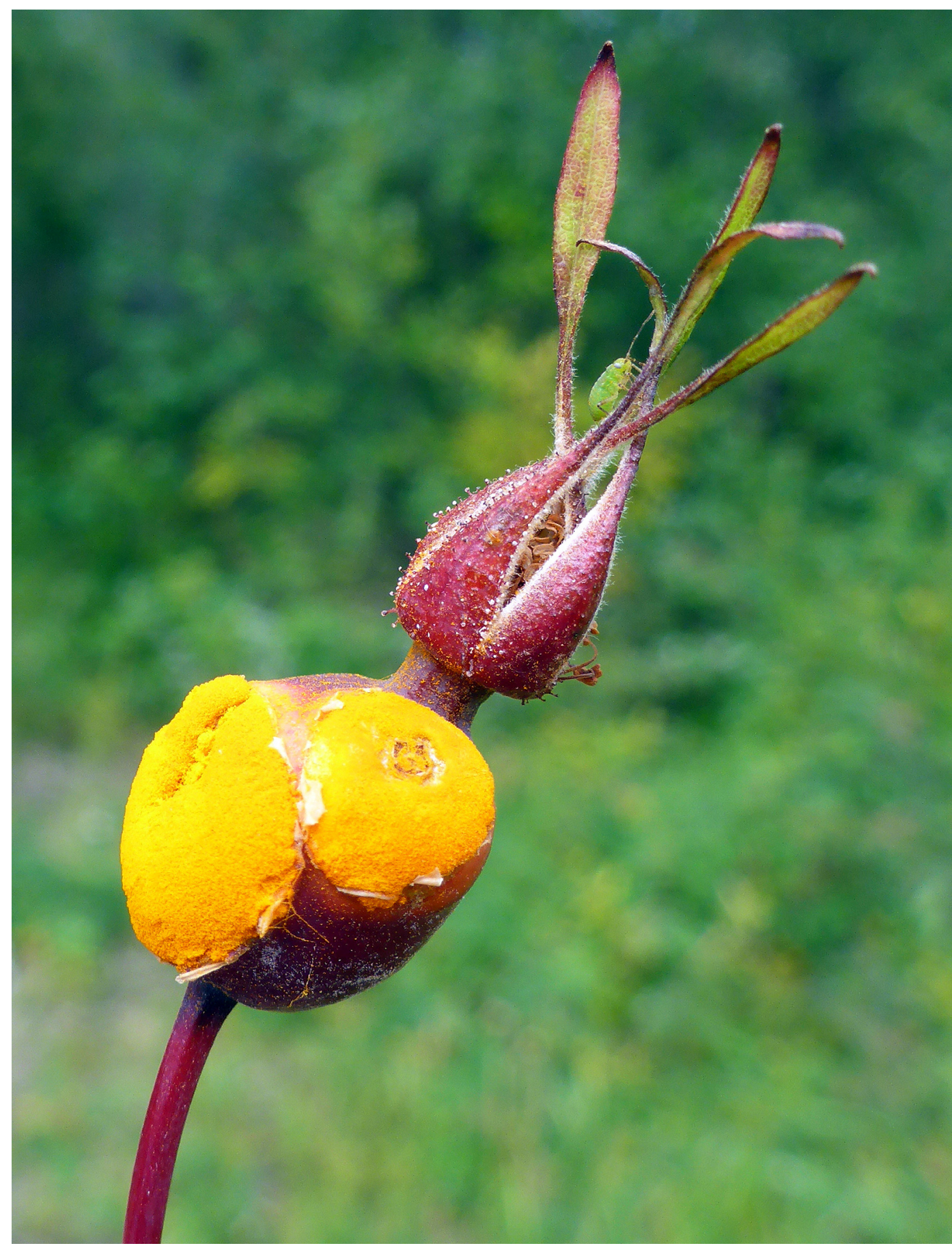

Figure 7. Powdery rust fungus, Phragmidium, on wild Prickly Rose (Rosa acicularis). Boot Lake Trail. 30 July 2017. Photo: P. M. Catling. 


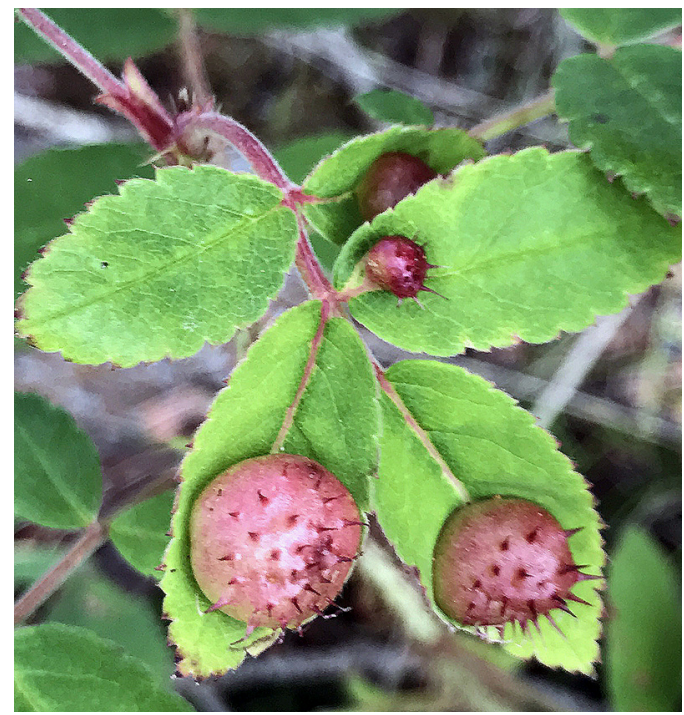

FiguRE 8. Prickly gall on wild Prickly Rose (Rosa acicularis) caused by a minute chalcidoid gall wasp of the genus Diplolepis (possibly D. bicolor). 30 July 2017. Photo: P. M. Catling.

outside of town and may be indicators of a kind of a habitat more frequent in the past and/or localized in the delta region.

Norman Wells (2 August 2017, Historical Centre and the Mackenzie River shoreline, $65.2782^{\circ} \mathrm{N}$, $\left.126.8175^{\circ} \mathrm{W}\right)$. The biological inventory of Norman Wells included the Mackenzie River shoreline and numerous habitats and trails around town. The diversity and complexity of the Mackenzie River flood shore was a major highlight. The highest water level, indicated by the accumulation of driftwood, was at least $15 \mathrm{~m}$ above the water level in early August when we visited (Figure 9). Since the spring, the river had gradually receded leaving land exposed for varying lengths of time and allowed the growth of a diversity of plants at different zones along the shoreline. This led to unusually high plant and animal species diversity. Many of the species present are restricted to this habitat type. Data were collected to evaluate the extent of invasion of the floodshore by the non-native plant, White Sweetclover (Melilotus albus Medikus). This is a fast-growing, fast-spreading, and highly competitive plant and the prospect of losing native plants to this and other non-native competitors before we have discovered all of their values is at least a little worrying. Other plants, such as the rare (in NWT) Alaska Wild Rhubarb (Aconogonon alaskanum (W. Wight ex Harshberger) Soják), are potentially important as new Arctic crops. During our visit we found out that the southern limit of this plant (and the site of the population most adapted to a warming climate) was at Tulita.
A gall caused by the Poplar Petiole Gall Aphid, Pemphigus, possibly P. populitransversus (Figure 10), on Balsam Poplar (Populus balsamifera L.) along the Mackenzie was something that we had not seen before. This turned out to be even more interesting because one of the galls contained a parasitic fly larva $1.5 \mathrm{~cm}$ long. Aphids that induce closed galls are usually parasitoid free, but parasitoids have been identified from galls in Japan (Takada et al. 2010). This may be one of the few cases of parasitism of gall-forming aphids reported in North America.

The Graceful Sedge Grasshopper (Stethophyma gracile; Figure 11) recorded at Norman Wells is only the second record for the species in NWT and is $700 \mathrm{~km}$ northwest of the previous record from near Kakisa on the south side of Great Slave Lake (Catling 2008). This extension of known range may be a result of a climate that is changing faster than many other regions of the world (Environment and Natural Resources 2016).

Three insect species that have been assessed by the Committee on the Status of Endangered Wildlife in Canada were recorded in Norman Wells: Transverse Lady Beetle (Coccinella transversoguttata) and Yellow-banded Bumble Bee (Bombus terricola), both species of "Special Concern" (COSEWIC 2016, 2015, respectively), and Gypsy Cuckoo Bumble Bee (Bombus bohemicus, Figure 12) an "Endangered" species (COSEWIC 2014b). Numerous other more common bumble bee species were also recorded. These are exciting results, especially Gypsy Cuckoo Bumble Bee, because this bee historically ranged throughout Canada although in the last decade has only been found in northern Canada (COSEWIC 2014b).

Fort Simpson (9 August 2017, Town Golf Course, $61.8586^{\circ} \mathrm{N}, 121.3547^{\circ} \mathrm{W}$ ). This event focussed on macrofungi, lichens, and mosses and involved a group of experts in these groups (see authors and acknowledgements). The community was invited to a walk at the golf course to find examples and later to examine some of the species collected on display tables. Collecting around the Yellowknife area continued from 10 to 12 August. While it was extremely dry during this period, the diversity of macrofungi was surprisingly high (Figure 13). Around 115 collections were made from the Fort Simpson area and 78 from the Yellowknife area. It is estimated that there were $130-150$ species found. The icicle fungi Hericium abietis (Figure 14), $H$. coralloides, and H. erinaceus were spectacular. Most species collected were first reports for NWT. Because Hebeloma expert, Dr. Henry Beker, was present, collecting focussed on finding as many Hebelomas as possible. None were found at Fort Simpson, but at least three different species were found in Yellowknife. The collections continue to be examined and they will contribute to the very incomplete documentation of these groups in NWT. Only eight species were listed in NWT 


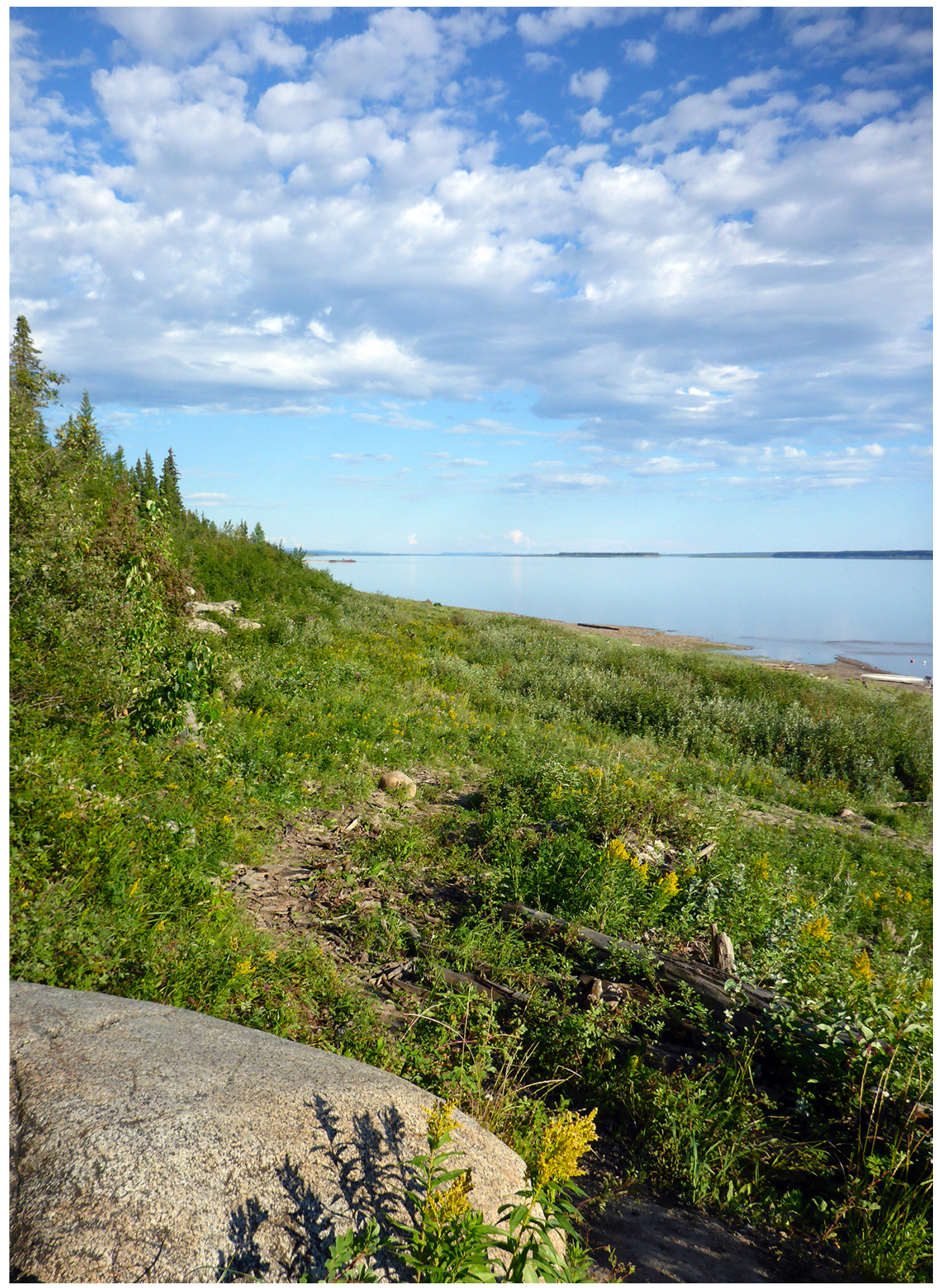

FIGURE 9. Mackenzie River flood shore. Within this habitat the Yellow-banded Bumble Bee (Bombus terricola) and Transverse Lady Beetle (Coccinella transversoguttata), both species of "Special Concern" (COSEWIC 2015, 2016) were observed in abundance. 2 August 2017. Photo: P. M. Catling. 


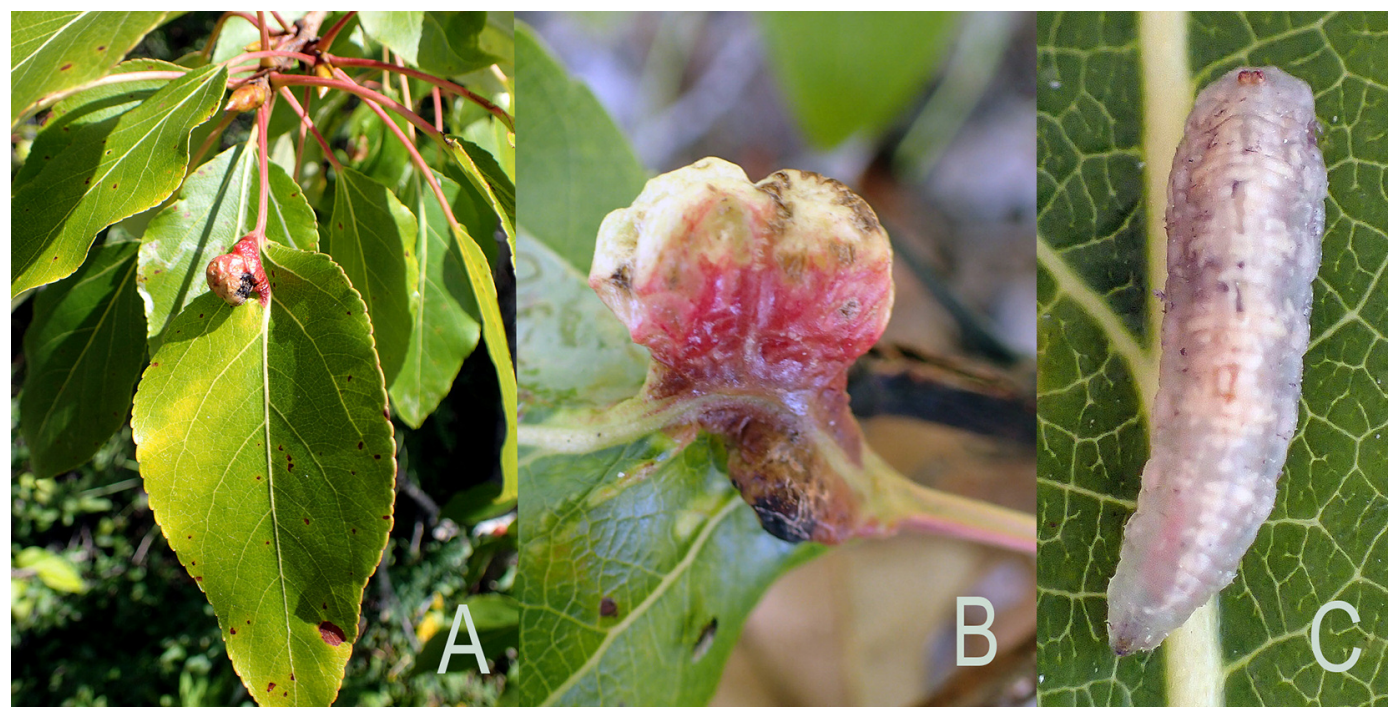

Figure 10. A) A gall caused by the Poplar Petiole Gall Aphid, Pemphigus cf. populitransversus; B) closer view of gall; and C) fly larva from inside gall. 2 August 2017. Photo: P. M. Catling.

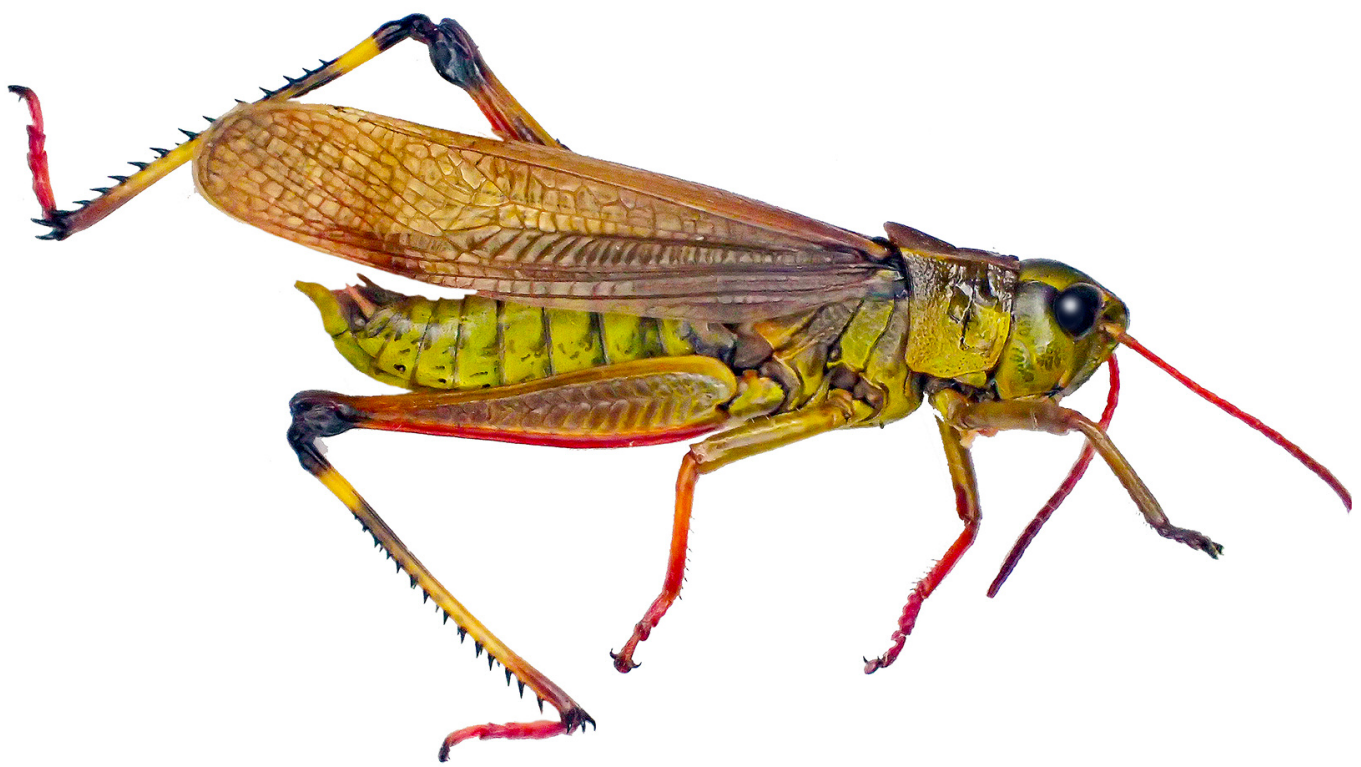

FIGURE 11. The Graceful Sedge Grasshopper (Stethophyma gracile) found at Norman Wells was only the second record for the Northwest Territories and a range extension of $700 \mathrm{~km}$ northwest. 2 August 2017. Photo: P. M. Catling.

Species 2016-2020 (Working Group on General Status of NWT Species 2016).

Yellowknife (12 August 2017, Prince of Wales Heritage Centre, $\left.62.4575^{\circ} \mathrm{N}, 114.3776^{\circ} \mathrm{W}\right)$. In Yellowknife, the outdoor exploratory part of the BioBlitz included the areas near the museum at the west end of Frame Lake and northwest to Niven Lake. Clear-winged Grasshopper (Camnula pellucida), common in dry open ground, was a new record for the Yellowknife area. Eighteen species of birds were recorded in two hours during an early morning bird survey at Niven Lake led by Suzanne Carrière. Earthworms were found at a few places in town and later as far away as the Prelude Lake boat launch. They are not native to NWT but introduced, likely from Europe via southern Canada. Also notable was the Black Meadowhawk dragonfly (Sympetrum danae) which was the most common (68 seen) of eight dragonfly species in the BioBlitz area. It is usually local and uncommon and none have been seen in the previous dragonfly counts in this area, but 


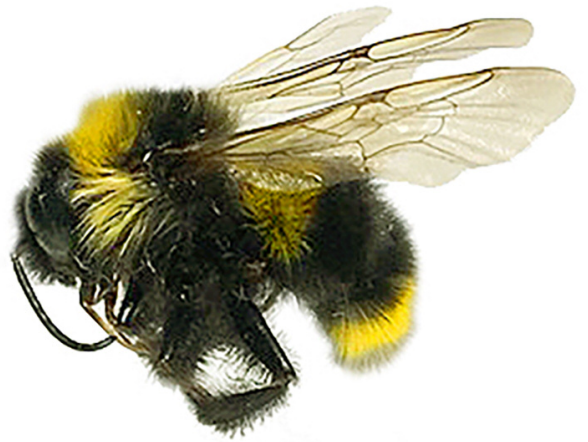

Figure 12. This Gypsy Cuckoo Bumble Bee (Bombus bohemicus) was one of many unusual insects found in Norman Wells. It is a nationally "Endangered Species" (COSEWIC 2014b). Like several other endangered species, its northern populations are the most viable in Canada. 31 July 2017. Photo: C. Sheffield.

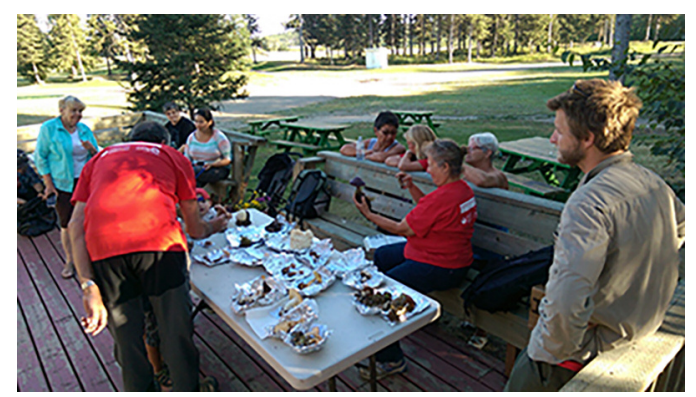

Figure 13. Mushrooms at Fort Simpson. 8 August 2017. Photo: Linda Davies.

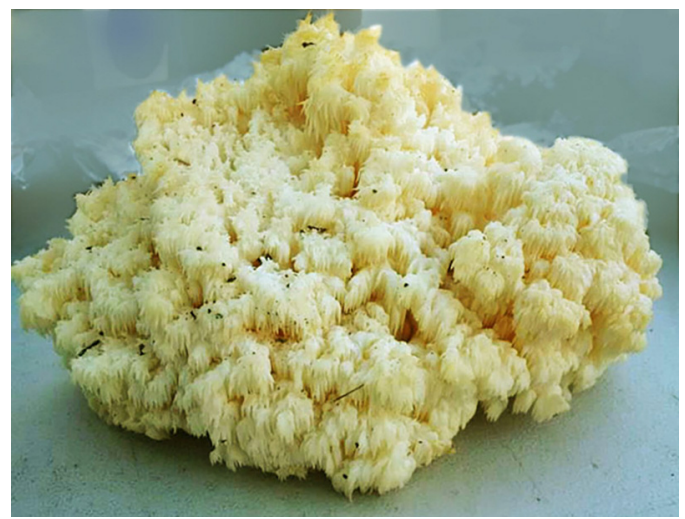

FiguRE 14. Lion's Mane (Hericium abietis), an icicle fungus, from near Mackenzie River $1 \mathrm{~km}$ north of N'Dulee Ferry Crossing. August 2017. Photo: Sharmin Gamiet. those counts were in July. Bumble bees were popular with children during the BioBlitz event here and elsewhere (Figure 15). Although the declines in NWT have been less than elsewhere (Working Group on the Status of NWT Species 2016), some bumble bees are rapidly declining in NWT. To assist in monitoring this group of valuable pollinators and environmental indicators, the Government of the Northwest Territories (2017) has produced a free guide.

On the day before the main BioBlitz event at Yellowknife, there was a related event: a tour with members of the non-profit organization, the Yellowknife Association for Community Living. It supports people with disabilities and their families, across their lifetime and aims to help them live meaningful lives and be active in all aspects of community life. The event took place at the Yellowknife River day-use area on the Ingraham Trail. It was well attended; 30 children and youth ages 5 to 15 years joined us for a walk through the woodland trails along the shores of the river. Large insects and spiders were the main attraction, the first observation being a large female orb spider who the group affectionately named "Susan". There were numerous questions about Susan's biology, life cycle, number of eggs, lifespan, and hibernation. Interest in the spider was only exceeded by a pair of huge $(15 \mathrm{~cm}$ wingspan, 5-8 cm long) Lake Darner dragonflies (Aeshna eremita), a female and male that were captured by net while holding each other in a mating position (in tandem). Everyone wanted to hold a dragonfly and all were given the opportunity; each participant held the dragonfly carefully by the folded wings and noted the difference between the sexes, their spectacular colours, and their huge eyes. The giant insects were then passed gently to the next person. After each person had their turn at holding each dragonfly, the insects were placed on an open palm and after only brief hesitation, flew away unharmed. No damage after a handhold by each of 30 kids! What a wonderful demonstration of care and sensitivity.

BioBlitzes are special events that bring together community members with a common interest in nature and in learning more about the natural world. We were delighted to be part of these events to make new friends in each of these communities, learn from them, and share a respect for nature.

The species observed during the BioBlitz Canada project were recorded using iNaturalist. Species lists can be viewed by following the links below.

Tuktoyaktuk: http://inaturalist.ca/projects/tuktoyaktuk-bioblitz-2017-de-tuktoyaktuk.

Inuvik: http://inaturalist.ca/projects/inuvik-bioblitz2017-de-inuvik.

Norman Wells: http://inaturalist.ca/projects/normanwells-bioblitz-2017-de-norman-wells.

Yellowknife: http://inaturalist.ca/projects/yellowknifebioblitz-2017-de-yellowknife. 


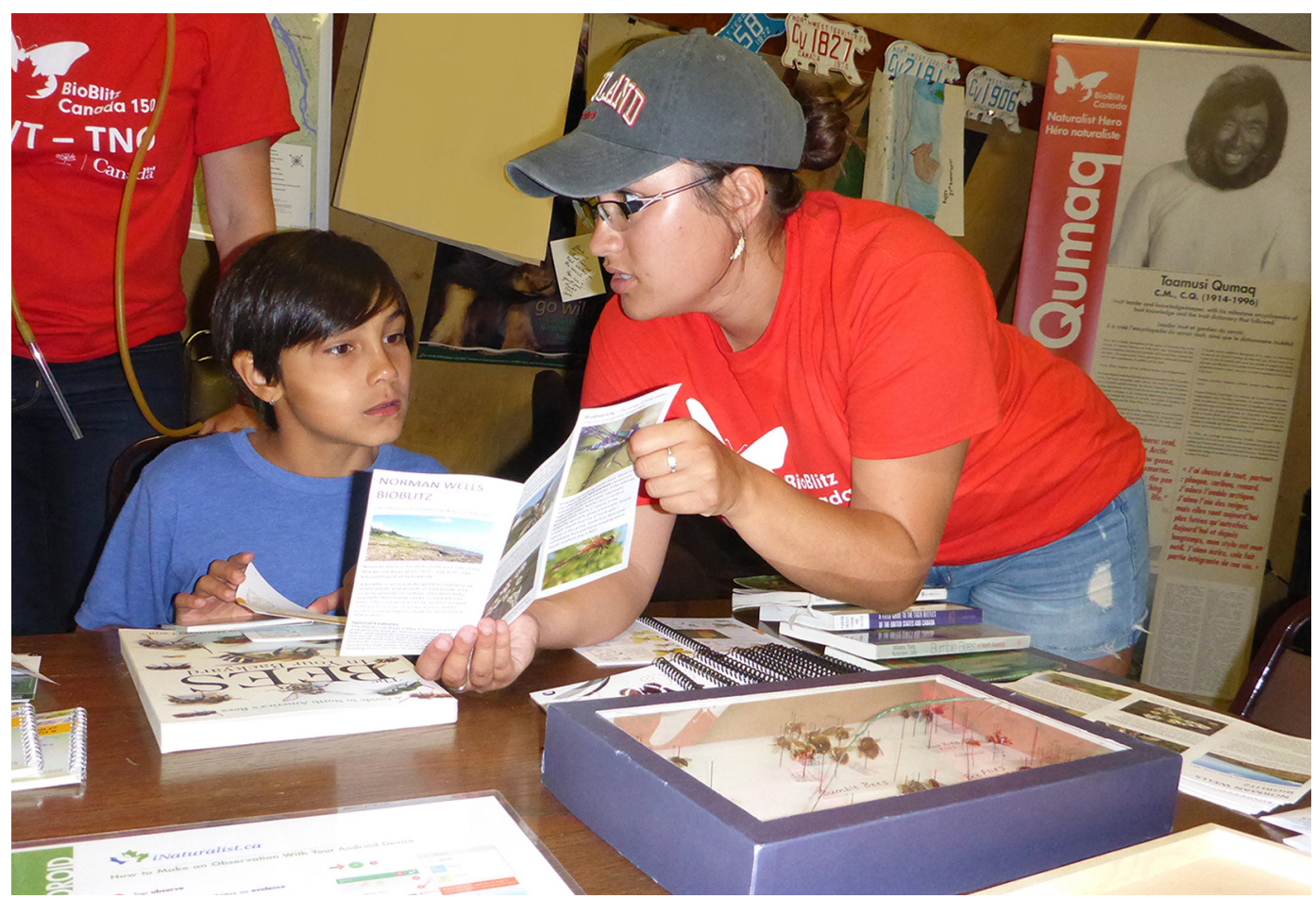

FIgurE 15. Monique Chapman assists in bee identification at the Norman Wells BioBlitz. 2 August 2017. Photo: B. Kostiuk.

\section{Acknowledgements}

Numerous people were involved in documenting species and coordinating access and logistics. In particular, Suzanne Carrière, Wildlife Biologist (Biodiversity), Government of the Northwest Territories (GNWT), played a key role. Stephanie Yuill, also of GNWT, played a major role in organizing the Yellowknife BioBlitz and Julie Ross, Centre Director, made the outstanding facilities of Yellowknife's Prince of Wales Heritage Centre available. Great help was also provided by: Sister Fay Tromblay and Roy and Julia Cockney of Tuktoyaktuk; Catarina Owen, Annika Trimble, and Erika Hille of the Aurora Research Institute in Inuvik; Wesley Hodgson, Richard and Napache Popko, and Dave Wilderspin of Norman Wells; and Henry Beker, Linda Davies, Diane Haughland, Toby Spribille, Karen Golinski, Tim Wheeler, and Spencer Goyette at the Fort Simpson and Yellowknife BioBlitzes.

\section{Literature Cited}

Aiken, S. G., M. J. Dallwitz, L. L. Consaul, C. L. McJannet, R. L. Boles, G. W. Argus, J. M. Gillett, P. J. Scott, R. Elven, M. C. LeBlanc, L. J. Gillespie, A. K. Brysting, H. Solstad, and J. G. Harris. 2007. Flora of the Canadian Arctic Archipelago: descriptions, illustrations, identification, and information retrieval. NRC Research Press, National Research Council of Canada, Ottawa, Ontario, Canada. Accessed 27 December 2017. http://nature.ca/aaflora/ data.
Canadian Wildlife Federation. 2017. BioBlitz Canada 150 events. Accessed 27 December 2017.

http://bioblitzcanada.ca.

http://bioblitzcanada.ca/about_bbc.aspx.

http://bioblitzcanada.ca/events_map.aspx.

http://bioblitzcanada.ca/events_community-northwestterritories.aspx.

http://bioblitzcanada.ca/project_bioblitz-in-a-box.aspx\# toc-2-10-check-list-of-items-to-include-in-final-reportto-the-canadian-wildlife-federation-.

Catling, P. M. 2008. Grasshoppers and related insects of Northwest Territories and adjacent regions. Environment and Natural Resources, Government of the Northwest Territories, Yellowknife, Northwest Territories, Canada.

COSEWIC (Committee on the Status of Endangered Wildlife in Canada). 2014a. COSEWIC assessment and status report on the Red-necked Phalarope, Phalaropus lobatus, in Canada. COSEWIC, Ottawa, Ontario, Canada. Accessed 18 May 2018. http://sararegistry.gc.ca/virtual sara/files/cosewic/sr_Red-necked Phalarope_2014_e.pdf.

COSEWIC (Committee on the Status of Endangered Wildlife in Canada). 2014b. COSEWIC assessment and status report on the Gypsy Cuckoo Bumble Bee Bombus bohemicus in Canada. COSEWIC, Ottawa, Ontario, Canada. Accessed 17 May 2018. http://sararegistry.gc.ca/virtual _sara/files/cosewic/sr_GypsyCuckooBumbleBee_2014_e. pdf.

COSEWIC (Committee on the Status of Endangered Wildlife in Canada). 2015. COSEWIC assessment and status report on the Yellow-banded Bumble Bee Bombus 
terricola in Canada. COSEWIC, Ottawa, Ontario, Canada. Accessed 17 May 2018. http://sararegistry.gc.ca/virtual sara/files/cosewic/sr_Yellow-banded_BumbleBee_2015_e. pdf.

COSEWIC (Committee on the Status of Endangered Wildlife in Canada). 2016. COSEWIC assessment and status report on the Transverse Lady Beetle Coccinella transversoguttata in Canada. COSEWIC, Ottawa, Ontario, Canada. Accessed 17 May 2018. http://sararegistry.gc.ca/ virtual_sara/files/cosewic/sr_Transverse_Lady_Beetle_20 16 e.pdf.

Environment and Natural Resources. 2016. NWT state of the environment report - highlights 2016. Department of Environment and Natural Resources, Government of the Northwest Territories, Yellowknife, Northwest Territories, Canada. Accessed 27 December 2017. http://www.enr. gov.nt.ca/sites/enr/files/state_of_environment_highlights 2016.pdf.

Government of the Northwest Territories. 2017. A Field Guide to the Bumble Bees of the Northwest Territories. Government of the Northwest Territories, Yellowknife, Northwest Territories, Canada.

Takada, H., K. Kamijo, and H. Torikura. 2010. An aphidiine parasitoid Monoctonia vesicarii (Hymenoptera: Braconidae) and three chalcidoid hyperparasitoids of Pemphigus matsumurai (Homoptera: Aphididae) forming leaf galls on Populus maximowiczii in Japan. Entomological Science 13: 205-215. https://doi.org/10.1111/j.1479-8298.2010.00 374. $\mathrm{x}$

Percy, J. A. 1983. Distribution of arctic marine isopods of the Mesidotea (=Saduria) complex in relation to depth, temperature, and salinity in Southern Beaufort Sea. Arctic 36: 341-249.

Preble, E. A. 1908. A biological investigation of the Athabasca-Mackenzie region. North American Fauna 27. United States Department of Agriculture, Bureau of Biological Survey, Washington, DC, USA.

Working Group on General Status of NWT Species. 2016. NWT Species 2016-2020 - general status ranks of wild species in the Northwest Territories. Department of Environment and Natural Resources, Government of the Northwest Territories, Yellowknife, Northwest Territories, Canada. Accessed 27 December 2017. http://www.nwtspe ciesatrisk.ca/sites/default/files/nwtspecies_2016_2020_re port_final_w_properties.pdf.

Paul M. Catling, Brenda Kostiuk Ottawa, ON, Canada

JENNIFER HERON

B.C. Ministry of Environment, Surrey, BC, Canada

RUNEL JIMENEZ Yellowknife, NWT, Canada

Monique Chapman Halifax, NS, Canada

SHARMIN GAMIET Mycology Resources, Abbotsford, BC, Canada

Velma STERENBERG Yellowknife, NWT, Canada 